\title{
KONSEP PENDIDIKAN MULTIKULTURAL SEBAGAI SARANA ALTERNATIF PENCEGAHAN KONFLIK
}

\author{
Yuli Adhani \\ Universitas Negeri Jakarta \\ Email: adhaniyuli@yahoo.co.id
}

\begin{abstract}
This article provided an overview of the concept of multicultural education as an alternative means of conflict prevention. The method used to support the writing of this article is the study of literature. Point of this article is that multicultural education is a process of developing the full potential of buman being respectful to plurality and heterogeneity as a consequence of the diversity of culture, ethnicity, religion, economic, social and political background. As one of the world's biggest multicultural country, Indonesiais supposed develop multicultural education as an alternative to prevent social and cultural conflict that often occurs in Indonesia. In addition build a multicultural society in Indonesia can not be taken for granted by trial and error. On the contrary building multicultural society should be pursued in a systematic, programmatic, integrated and sustainable. This is because the multicultural reality in Indonesia is an asset that makes Indonesian culturallu very rich. Therefore, it is necessary for Indonesia to maintain and preserve its rich culture.

Keywords: multicultural education, conflict
\end{abstract}

\begin{abstract}
Abstrak
Artikel ini dimaksudkan untuk memberikan gambaran tentang konsep pendidikan multikultural sebagai sarana alternatif pencegahan konflik. Metoda yang digunakan untuk mendukung penulisan artikel ini adalah studi kepustakaan. Beberapa poin utama dalam artikel ini adalah bahwa pendidikan multikultural merupakan proses pengembangan seluruh potensi manusia yang menghargai pluralitas dan heterogenitas sebagai konsekuensi keragaman budaya, suku, agama, ekonomi, sosial dan politik. Sebagai salah satu negara multikulural terbesar didunia sudah seharusnya Indonesia mengembangkan pendidikan multikultural sebagai salah satu alternatif mencegah konflik sosial budaya yang sering kali terjadi di Indonesia. Pembangunan masyarakat multikultural Indonesia tidak bisa dengan cara taken for granted atau trial and error, sebaliknya harus diupayakan secara sistematis, programatis, integrated dan berkesinambungan. Hal ini dikarenakan realitas multikultural yang ada di Indonesia merupakan kekayaan dan kekuatan budaya yang sepatutnya dijaga dan dilestarikan.
\end{abstract}

Kata kunci: pendidikan multikultural, konflik

\section{A. Pendahuluan}

Indonesia merupakan salah satu negara yang multikultural terbesar di dunia. Pernyataan ini dapat dibenarkan ketika kita melihat kondisi sosiokultural maupun geografis yang begitu beragam dan luas yang dimiliki Indonesia. Keragaman ini dapat menjadi rahmat sekaligus bencana apabila sesama anak bangsa tidak memahami hakekat berbangsa dan bernegara dalam naungan Bhinneka Tunggal Ika. Nyatanya kebhinekaan tersebut justru menjadi pemicu konflik yang dikhawatirkan berakhir pada disintegrasi bangsa. Selama lebih dari satu dasawarsa terakhir, rangkaian konflik dan kekerasan bernuasa SARA terus terjadi di Indonesia. Mulai dari kerusuhan antaragama di kota-kota provinsi pada 1995-1997, kampanye anti dukun santet di Jawa dan konflik antarkelompok agama di Sulawesi Tengah dan Maluku pada 1998-2001, hingga mobilisasi 
laskar berbasis agama dan pengeboman yang dilakukan kelompok teroris atas nama "jihad" pada 2000-2005. Selain itu, konflik dan kekerasan sektarian yang menimpa Jamaah Ahmadiyah Indonesia dan aliran-aliran keagamaan lainnya telah menambah deret hitung insiden konflik dan kekerasan bernuansa agama di Indonesia.

Menurut hasil penelitian Ali-Fauzi dkk. hampir di seluruh wilayah Indonesia pernah mengalami konflik keagamaan dengan menggunakan aksi damai ataupun kekerasan seperti yang digambarkan Tabel 1 di bawah ini:

Tabel 1

Persebaran Insiden Konflik Keagamaan Menurut Provinsi, 1990-2008

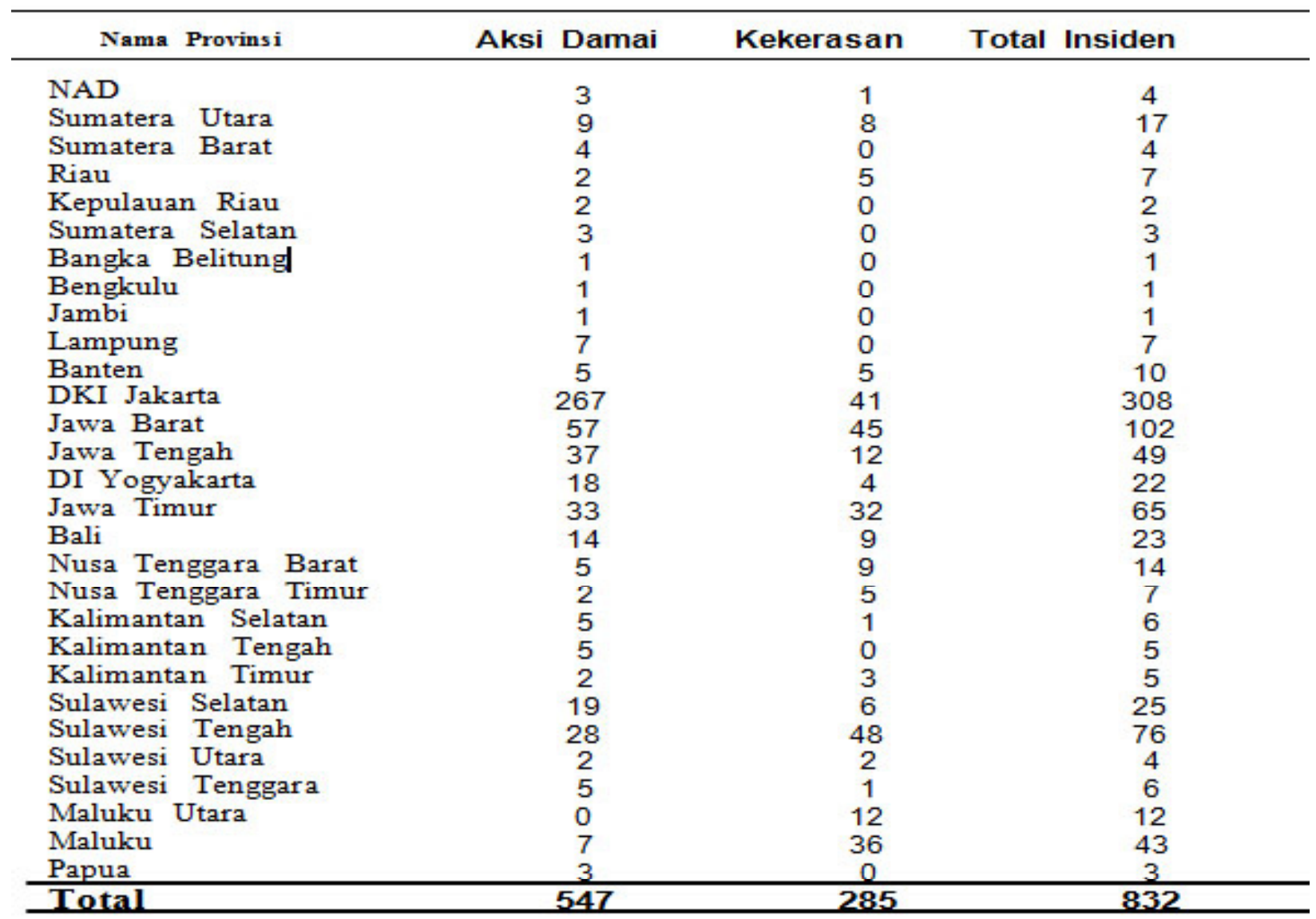

Lebih rendahnya tingkat aksi kekerasan dibanding aksi damai dalam insiden konflik keagamaan sesungguhnya merupakan fenomena umum yang juga terjadi di tempat atau negara-negara lain. Namun, hal ini bukan berarti aksi kekerasan memiliki signifikansiyang lebih rendah. Karena, betapapun rendahnya tingkat aksi kekerasan, hal ini tetap penting mengingat dampak yang dihasilkannya, baik berupa korban jiwa maupun kerusakan harta-benda. Untuk menggambarkan hal ini, kalangan ahli ilmu sosial lazim menggunakan istilah "kecil tetapi penting" (the significant small).

Data di atas sebaiknya dibaca dari perspektif yang lebih luas, bahwa masyarakat Indonesia sesungguhnya memiliki kemampuan untuk mewujudkan respon mereka terhadap isu-isu yang memicu konflik dalam bentuk aksi-aksi damai, baik berupa protes maupun upaya-upaya yang memberi kontribusi pada penyelesaian konflik yang terjadi. Persoalannya kemudian adalah bagaimana mendorong agar masyarakat tetap menjadikan aksi damai sebagai pilihan utama mereka dalam merespons berbagai isu konflik. Untuk itu salah satu caranya adalah dengan menggali nilai-nilai kearifan (kearifan sosial dan kearifan budaya) dapat dijadikan sebagai tali pengikat dalam upaya bersosialisasi dan berinteraksi antar individu dengan individu, individu dengan kelompok, dan kelompok dengan kelompok. Dengan nilai kearifan sosial dan kearifan budaya, akan berusaha mengeliminir berbagai perselihan yang kurang kondusif. Tatanan kehidupan sosial masyarakat 
yang multikultural akan terwujud dalam perilaku yang saling menghormati, menghargai perbedaan keanekaragaman kebudayaan dan agama dalam prinsip kesederajatan. Selain itu emberio atau mendasari terjadinya konflik bukan hanya perbedaan budaya dan agama tetapi dapat terjadi dikarenakan prasangka historis, diskriminasi, perasaan superioritas in-group feeling yang berlebihan dengan menganggap inferior pihak yang lain (out-group)". ${ }^{1}$

Nalar masyarakat tentang konsep multikultural masih terpaku pada tafsir hegemonik yang sarat dengan prasangka, kecurigaan, bisa kebencian, dan reduksi terhadap kelompok yang berada di luar dirinya (the other). Akibatnya ikatan-ikatan sosial melalui kolektivitas dan kerjasama hanya berlaku di dalam kelompoknya sendiri (in group), tidak berlaku bagi kelompok lain (other group). Buktinya, konflik dan kekerasan hingga kini masih terjadi dalam bentuk dan motif yang beragam di beberapa wilayah Indonesia, termasuk di dalam lingkungan perguruan tinggi hal ini dipaparkan dalam penelitian "dinamika konflik sosial dalam bentuk tawuran mahasiswa yang berujung pada perilaku kekerasan yang terjadi di kota Makassar". ${ }^{2}$

Untuk mengantisipasi potensi negatif konflik secara berkepanjangan di masa depan, perlu dikembangkan dalam dunia pendidikan formal dan nonformal tentang konsep pendidikan multikultural bagi setiap warga negara Indonesia. Hal ini dimaksudkan agar warga negara memiliki kepekaan dalam menangkap dan menghadapi perbedaan yang sebagai sesuatu yang given, takdir Tuhan, dan bukan bentukan manusia. Seharusnya masyarakat harus memahami sepenuhnya bahwa setiap manusia terlahir berbeda, baik secara fisik maupun non fisik, tetapi nyatanya sebagian masyarakat belum bisa menerima realitas bahwa setiap individu atau kelompok tertentu memiliki sistem keyakinan, budaya, adat, agama, ekonomi, sosial, politik yang berbeda.

\footnotetext{
1 Andrik Purwasito, Komunikasi Multikultural, Surakarta : UMS Press, 2003, h. 147.

2 Jumadi, "Dinamika konflik sosial dalam bentuk tawuran mahasiswa di Kota Makassar". Disertasi PPS UNHAS: tidak diterbitkan. 2009.
}

\section{B. Pembahasan \\ 1. Pengertian Pendidikan Multikultural}

Istilah pendidikan multikultural secara etimologis terdiri dari dua terma, yaitu pendidikan dan multikultural. Pendidikan merupakan usaha sadar dan terencana untuk mewujudkan suasana belajar agar peserta didik secara aktif mengembangkan potensi dirinya untuk memiliki kekuatan spiritual keagamaan, pengendalian diri, kepribadian, kecerdasan, akhlak mulia, serta keterampilan yang diperlukan dirinya, masyarakat, bangsa dan negara. Sedangkan secara terminologis, pendidikan multikultural merupakan proses pengembangan seluruh potensi manusia yang menghargai pluralitas dan heterogenitas sebagai konsekuensi keragaman budaya, etnis, suku dan aliran (agama), ekonomi, sosial dan politik. ${ }^{3}$

Meminjam pendapat Andersen dan Cusher, bahwa pendidikan multikultural dapat diartikan sebagai pendidikan mengenai keragaman kebudayaan. ${ }^{4}$ Kemudian, James Banks mendefinisikan pendidikan multikultural sebagai pendidikan untuk people of color. Artinya, pendidikan multikultural ingin mengeksplorasi perbedaan sebagai keniscayaan (anugerah Tuhan/Sunnatullab). Kemudian bagaimana kita mampu menyikapi perbedaan tersebut dengan penuh toleran dan semangat egaliter. ${ }^{5}$

Berbeda dengan pengertian pendidikan multikultural yang dikemukakan para pakar pendidikan multikultural di atas, dalam bukunya Multicuctural Education: A Teacher Guide to Linking Context, Process and content, karya seorang pakar pendidikan multikultural di Califonia State University, Amerika Serikat, Hilda Hernandez mengartikan pendidikan multikultural sebagai perspektif yang mengakui realitas politik, sosial, dan ekonomi yang dialami oleh masingmasing individu dalam pertemuan manusia yang kompleks dan beragam secara kultur, dan merefleksikan pentingnya budaya, ras, seksualitas dan gender, etnisitas, agama, status sosial, ekonomi, politik dan pengecualian dalam proses pendidikan. ${ }^{6}$ Pandangan tersebut dapat

\footnotetext{
3 Maslikhah, Quo Vadis Pendidikan Multikultural Rekonstruksi Sistem Pendidikan Berbasis Kebangsaan, Jawa Tengah: JP Books, 2007, hal. 47-48.

4 Andersen, R. dan Cusher, K., Multicultural and intercultural studies, dalam Teaching Studies of Society and Environment (ed. Marsh,C.). Sydney: Prentice-Hall, 1994, h. 320.

5 James Banks, Educating Citizens in a Multikultural Society, New York and London: Teachers College Columbia University, 1997, h. 3.

6 Hilda Hernandez, Multicultural Education: A Teacher Guide to
} 
dimaknai bahwa ruang pendidikan multikultural sebagai media transpormasi ilmu pengetahuan (transfer of knowledge) hendaknya mampu memberikan nilai-nilai multikulturalisme dengan saling menghargai dan menghormati atas realitas yang beragam (pluralis), baik latar belakang maupun basis sosial budaya yang melingkupinya.

National Association for Multicultural Education sebagaimana dikemukakan Azra menguraikan tiga perspektif pengertian pendidikan multikultural. Pertama, pendidikan multikultural sebagai konsep filosofis yang berlandaskan pada ide kemerdekaan, keadilan, kesamaan, hak kekayaan, dan martabat kemanusiaan. Kedua, pendidikan multikultural sebagai proses yang meliputi semua aspek praktek sekolah, kebijakan dan organisasi sebagai alat untuk memastikan tingkat prestasi akademis para siswa. Ketiga, pendidikan multikultural memperkuat keyakinan bahwa semua peserta didik, riwayat hidup dan pengalamannya harus ditempatkan sebagai pusat dalam proses pengajaran dan pembelajaran dan pembelajaran harus didasarkan pada konteks yang dekat (terbiasa) dengan peserta didik dan menunjukkan berbagai cara berpikir. ${ }^{7}$

Pendidikan multikultural dapat pula dilihat dari 3 (tiga) aspek, yaitu an idea or concept, an educational reform movement, and a process (ide atau konsep, gerakan pembaruan pendidikan, dan proses), ${ }^{8}$ sehingga pendidikan multikultural merupakan suatu proses dari perubahan sekolah yang menyeluruh dan pendidikan dasar untuk semua siswa. Pendidikan ini menentang dan menolak segala bentuk rasisme dan bentuk lain dari diskriminasi di sekolah dan masyarakat dan menerima dan mengakui pluralisme (etnik, ras, bahasa, agama, ekonomi, gender, dan lainnya).

Selain itu, Banks mengidentifikasi lima dimensi pendidikan multikultural, yaitu: (1) content integration, mengintegrasikan berbagai budaya dan kelompok untuk mengilustrasikan konsep mendasar, generalisasi dan teori dalam mata pelajaran/disiplin ilmu, (2) the knowledge construction process, membawa siswa untuk

Linking Context, Process, and Content. New Jersey \& Ohio: Prentice Hall, 1989, h. 6.

Azyumardi Azra, Pendidikan Kewargaan dan Demokrasi di Indonesia, dalam Ikhwanuddin Syarif \& Domodo Murtadlo (eds), Pendidikan untuk masyarakat Indonesia baru: 70 Tahun Prof. Dr. HAR Tilaar Msc. Ed., (Jakarta:Grasindo, 2002), h. 13.

8 Op.Cit., h. 68. memahami implikasi budaya ke dalam sebuah mata pelajaran (disiplin), (3) an equity paedagogy, menyesuaikan metode pengajaran dengan cara belajar siswa dalam rangka memfasilitasi prestasi akademik siswa yang beragam baik dari segi ras, budaya ataupun social, (4) prejudice reduction, mengidentifikasi karakteristik ras siswa dan menentukan metode pengajaran mereka, dan (5) empowering school culture, melatih kelompok untuk berpartisipasi, berinteraksi dengan seluruh staf dan siswa yang berbeda etnis dan ras dalam upaya menciptakan budaya

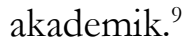

Dari dimensi pendidikan multikultural di atas, selanjutnya muncul tiga model pendidikan multikultural yaitu: (1) content-oriented programs, (2) student-oriented programs, dan (3) sociallyoriented programs. Pertama, content-oriented programs (program-program yang memfokuskan pada konten) merupakan jenis yang paling umum dalam pendidikan hubungan antaretnik dan multikultural. Sebagai contoh adalah materi masyarakat multikultural dalam mata pelajaran Sosiologi SM kelas XI. Dalam materi tersebut terdapat tiga topik pembelajaran yang lebih difokuskan pada perbedaan kelompok budaya dengan menempatkan beberapa pokok bahasan tentang integrasi sosial, masyarakat multikultural dan permasalahannya, dan perkembangan kelompok dalam masyarakat multikultural. Program ini lebih mendalam meliputi banyak materi multikultural yang masih melingkupi beberapa persoalan yang meliputi materimateri dan gagasan-gagasan mendalan tentang beberapa problem sosiokultural yang beragam. ${ }^{10}$

Contoh dari program ini adalah kajian etniketnik minoritas tradisional yang memerlukan pembinaan secara khusus terhadap etnik-etnik terasing tertentu, seperti kubu, sasak, baduy, tengger, dan sebagainya. Selanjutnya juga diungkap bagaimana etnik-etnik minoritas dapat "maju" sehingga memberikan kontribusi positif terhadap kemajuan masyarakat secara luas, baik melalui langkah-langkah integrasi sosial, asimilasi, akulturasi, dan sebagainya. Kedua, student-oriented programs (programprogram yang memfokuskan bagaimana siswa belajar), mencoba memunculkan karakteristik-

\footnotetext{
9 Ibid, h. 69.

10 Ibid, h. 77.
} 
karakteristik ataupun adat-istiadat yang dimiliki oleh masing-masing etnik minoritas tradisional, minoritas maju, maupun etnik-etnik besar (Jawa, Sunda, Minang, Batak, dan sebagainya).

Laporan UNDP 2004 menyatakan, berbagai studi kasus dan analisis menunjukkan, demokrasi yang bertahan dan berkelanjutan umumnya terdapat di negara-negara yang memiliki pendangan multikultural dan kemudian menerapkan multikulturalisme dalam berbagai kebijakan. Kebijakan-kebijakan responsive dan afirmatif sebagai bentuk "politics of recognition" yang menjadi dasar multikulturalisme memberikan intensif dalam penumbuhan dan penguatan perasaaan "kesatuan dalam keragaman. Lebih jauh dalam kerangka itu, seluruh warga negara dapat menemukan ruang politik dan institusional untuk mengidentifikasi diri mereka dengan negara-bangsa mereka sekaligus dengan identitas-identitas kultural lainnya. Semua ini mendorong tumbuhnya "trust" secara bersama-sama dalam diri warga negara, sehingga memperkuat partisipasi mereka dalam proses-proses politik demokratis. ${ }^{11}$

Jika dihubungkan dengan kondisi bangsa Indonesia saat ini kiranya menjadi sangat jelas bahwa pendidikan multikultural perlu dikembangkan di Indonesia. Dengan cara itu kita dapat memaknai "Bhinneka Tunggal Ika" secara tepat dan benar, seimbang dan proposional. Melalui kebijakan ini pula kita dapat menerapkan "persatuan Indonesia" dengan mengembangkan semangat nasionalisme sebagaimana diharapkan.

\section{Core Value Pendidikan Multikultur}

Core Value pendidikan multikurtur mengingatkan pada sirkulerisme pendidikan multikultur. Pada sirkulerisme pendidikan multikultur tersebut dapat mencakup hubungan empat dimensi yakni dimensi manusia dengan Allah, manusia dengan manusia, manusia dengan alam semesta dan manusia dengan dirinya sendiri. ${ }^{12}$ Dengan demikian, core value pada pendidikan multikultur mencapai totalitas hubungan yang menjadi titik pusat perhatian. Totalitas hubungan sesuai dengan derajat nilainilai diri, ketuhanan, kemanusiaan dan kealaman.

\footnotetext{
11 D. Budimansyah dan Suryadi, PKn dan Masyarakat Multikultural, Bandung: Program Studi PKn SPs UPI, 2008, h. 30.

12 Op.Cit., h. 70
}

Menurut Bannet dalam Maslikhah nilainilai inti (core value) yang mengarah pada tujuan pendidikan multikultur antara lain: ${ }^{13}$

a. Mengembangkan perspektif sejarah yang beragam dari kelompokkelompok masyarakat.

b. Memperkuat kesadaran budaya hidup di masyarakat.

c. Memperkuat kompetensi intelektual dari budaya-budaya yang hidup di masyarakat.

d. Memberi rasisme, sekisme dan berbagai jenis prasangka lainnya.

e. Mengembangkan kesadaran atas kepemilikan planet bumi dan mengembangkan keterampilan sosial.

Untuk mengawinkan core value tujuan pendidikan multikultural dengan fungsi dan tujuan pendidikan nasional dapat dikutip menurut Undang-undang Sistem Pendidikan Nasional No. 20 tahun 2003. DalamUU Sisdiknas dirumuskan fungsi dan tujuan pendidikan nasional untuk mengembangkan kemampuan dan membentuk watak serta peradaban bangsa yang bermanfaat dalam rangka mencerdaskan kehidupan bangsa, bertujuan untuk berkembangnya potensi perserta didik agar menjadi manusia yang beriman dan bertaqwa kepada Tuhan Yang Maha Esa, beraklak mulia, sehat, berilmu, cakap, kreatif, mandiri dan menjadi warganegara yang demokratis serta bertanggung jawab. Tujuan pendidikan nasional diatas tentu saja telah mengarahkan peserta didik untuk siap memiliki sikap multikultur sebagai hamba Tuhan Yang Maha Esa sudah seharusnya menerima keanekaragaman karena Tuhanlah yang menciptakan manusia bersukusuku, berbangsa-bangsa agar saling mengenal dan mampu hidup berdampingan sebagai khalifah di muka bumi.

Pendidikan di Indonesia secara perundangan telah diatur dengan memberikan ruang keragaman sebagai bangsa. UndangUndang Sistem Pendidikan Nasional Pasal 4 UU N0. 20 Tahun 2003 menjelaskan bahwa pendidikan diselenggarakan secara demokratis, tidak diskriminatif dengan menjunjung tinggi HAM, nilai keagamaan, nilai kultural, dan kemajemukan bangsa. Dasar perundangan ini 13 Ibid, h. 71. 
selain memberi arahan pendidikan di Indonesia juga mewajibkan bahwa pendidikan di Indonesia harus dikembangan berdasarkan nilai-nilai keagamaan, kultural, dan kemajemukan bangsa.

Wacana pendidikan multikultural di Indonesia yang didasarkan pada UU Sisdiknas di atas tidak dapat dilepaskan dengan gelombang reformasi pendidikan dunia. Sebagai bangsa, Indonesia tidak bisa lepas dari pengaruh dunia lebih luas, dengan demikian pendidikan multikultural berperan penting guna menyiapkan generasi bangsa sebagai bagian dari warganegara dunia (global citizenship). Globalisasi menjadikan keterikatan bangsa-bangsa sebagai kesatuan komunitas dunia. Sebagai bagian dari komunitas dunia warga negara dari suatu negara akan digerakkan oleh kesadaran akan persaudaraan kemanusiaan, hak asasi manusia, dan martabat sebagai manusia juga sikap seimbang antara kesadaran lokal seperti kecintaan terhadap keluarga, identitas etnik, kesadaran pada komunitasnya dan kepentingan diri dan global interests, seperti kesadaran universal tentang kesamaan umat manusia. Dewasa ini karakter warga negara yang ideal tidak saja dipengaruhi oleh kepentingan nasional tetapi harus pula mampu mengakomodasi perkembangan global. Hal ini dikarenakan warga negara tidak hanya dan tidak bisa hidup dalam lingkungan nasional tetapi juga hidup dengan bangsa lain dalam pergaulan internasional.

Berkaitan dengan hal tersebut, Cogan mengelompokkan kompetensi atau karakteristik yang harus dimiliki oleh warga negara multikultural abad ke-21 kaitannya dalam menunjang pendidikan multikultural di antaranya sebagai berikut: ${ }^{14}$

a. The ability to look at and approach problems as a member of a global society.

$b$. The ability to work with others in a cooperative way and to take responsibility for one's roles/ duties within society.

c. The ability to understand, accept, appreciate and tolerate cultural differences

d. The capacity to think in a critical and systemic way.

e. The willingness to resolve conflict and in a non-violent manner.

14 J.J. Cogan dan R. Derricot, Citizenship for the $21^{\text {st }}$ Century: An International Perspective on Education. London: Kogan Page, 1998, h. 115. f. The willingness to change one's lifestyle and consumption habits to protect the environment.

g. The ability to be sensitive towards and to defend buman rights (eg, rights of women, ethnic minorities, etc), and the willingness and ability to participate in politics at local, national and international levels.

Dengan kata lain, pendidikan multikultural akan membantu peserta didik untuk mengarahkannya ke kehidupan yang "kompleks" dan menjauhi pengertian yang sempit tentang ras, agama, suku, bahasa dan budaya. karena dalam hidup di era global setiap warga negara harus memahami isu-isu dan permasalahan global yang sangat kompleks pula seperti keanekaragaman budaya, politik, ekonomi, sosial, konflik dan perdamaian, ketergantungan antar bangsa di dunia, masalah HAM, masalah lingkungan, dan lain-lain, untuk itulah diperlukan karakteristik di atas maka warga negara multi dimensional dalam kaitannya dengan multikultural memiliki kemampuan untuk melihat, mengkritisi dan mampu untuk ikut serta dalam setiap segi kehidupan bukan hanya di tingkat lokal dan nasional bahkan mampu pada level internasional.

\section{Rancang Bangun Pendidikan Multikultur}

Pendidikan pada umumnya dinilai masih sangat penting sebagai salah satu aset sosial. Sebagai aset sosial berfungsi untuk mempertahankan keberadaan pendidikan yang disegani, diminati, dan terhindar dari persepsi marginal. Untuk mempertahankan label sebagai aset sosial, dituntut mampu memperbaharui perencanaan ditingkatan normatif maupun teknis. Pada tingkatan normatif antara lain review terhadap nilai-nilai filosofis kultural untuk menetapkan tujuan pendidikan yang dilaksanakan. Pada tingkatan teknis antara lain melaksanakan kurikulum sekaligus mengembangkan kurikulum, implementasi, dan evaluasi.

Rancang bangun untuk melaksanakan pendidikan multikultural menurut Tilaar disusun piranti sebagai berikut: ${ }^{15}$

a. Reformasi kurikulum.

15 H.A.R. Tilaar, Multikulturalisme, Tantangan-Tantangan Global Masa Depan dalam Transformasi Pendidikan Nsiona, Jakarta : Grasindo, 2004, h. $171-172$. 
b. Mengajarkan prinsip-prinsip keadilan sosial.

c. Mengembangkan kompetensi kurikulum.

d. Melaksanakan pedagogik kesataraan (equality pedagogy).

Piranti tersebut pada intinya dapat menunjukkan indikator yang jelas. Indikator dalam pendidikan yang mampu memanusiakan manusia sesuaidengan hak yangmelekat padanya. Di samping itu, pendidikan yang memberikan pengakuan sepenuhnya atas keberbedaan dirinya dengan komponen pluralitas yang menyangkut aspek etnis, budaya, agama, keyakinan, suku, dan peradaban. Jadi dapat dipahami bahwa untuk merancang pendidikan multikultural dalam program kurikuler, yakni melakukan reformasi kurikulum, mengajarkan prinsip-prinsip keadilan sosial, mengembangkan kompetensi kurikulum dan melaksanakan pedagogik kesataraan (equality pedagogy).

Mengacu kepada konsep kurikulum yang berbasis pendidikan multikultural, maka program pembelajaran yang dikembangkan harus memiliki kesesuaian dengan kebutuhan pebelajar dan kondisi sosial. Model pembelajaran multikultural yang dikembangkan diarahkan pada beberapa kompetensi dasar. Pertama, mengembangkan kompetensi akademik standar dan dasar (standar and basic academic skills) tentang nilaipersatuan dan kesatuan, demokrasi, keadilan, kebebasan, persamaan derajat atau saling menghargai dalam beraneka jenis keberagaman. Kedua, mengembangkan kompetensi sosial agar dapat menumbuhkan pemahaman yang lebih baik (a better understanding) tentang latar belakang budaya dan agama sendiri dan juga budaya dan agama lain dalam masyarakat. Ketiga, mengembangkan kompetensi akademik untuk menganalisis dan membuat keputusan yang cerdas (intelegent dicisions) tentang isu-isu dan masalah keseharian (real life problems) melalui sebuah proses demokratis atau penyelidikan dialogis (dialogical inquiry). Keempat, membantu mengkonseptualisasi dan mengaspirasikan konstruksi masyarakat yang lebih baik, demokratis, egaliter, tanpa ada diskriminasi, penindasan, dan pelanggaran terhadap nilai asasi universal. ${ }^{16}$

16 Ngainun Naim dan A. Sauwi, Pendidikan Multikultural: Konsep dan
Pengembangan kurikulum yang menggunakan pendekatan pendidikan multikultural haruslah didasarkan pada prinsip: (a) keragaman budaya menjadi dasar dalam menentukan filsafat, teori, model dan hubungan sekolah dengan lingkungan sosialbudaya setempat, (b) keragaman budaya menjadi dasar dalam mengembangkan berbagai komponen kurikulum seperti tujuan, konten, proses, dan evaluasi, (c) budaya di lingkungan unit pendidikan adalah sumber belajar dan objek studi yang harus dijadikan begian dari kegiatan belajar anak didik, dan (d) kurikulum berperan sebagai media dalam mengembangkan kebudayaan daerah dan kebudayan nasional.

Lebih lanjut bahwa pengembangan kurikulum masa depan yang berdasarkan pendekatan pendidikan multikultural dapat dilakukan berdasarkan lagkah-langkah berikut:

a. Mengubah filosofi kurikulum dari yang berlaku seragam kepada filosofi yang lebih sesuai dengan tujuan, misi dan fungsi setiap jenjang pendidikan dan unit pendidikan. Untuk tingkat pendidikan dasar, filosofi konservatif seperti esensialisme dan perenialisme haruslah dapat diubah ke arah filosofi kurikulum yang progresif seperti humanisme, progresivisme, dan rekonstruksi sosial, yang lebih menekankan pendidikan sebagai upaya mengembangkan kemampuan kemanusian peserta didik baik bagi individu maupun sebagai anggota masyarakat.

b. Teori kurikulum tentang konten (curriculum content) haruslah berubah dari teori yang mengartikan konten sebagai aspek substantif yang berisikan fakta, teori dan generalisasi kepada pengertian yang mencakup nilai, moral, prosedur, dan keterampilan yang harus dimiliki oleh anak didik.

c. Teori belajar yang digunakan dalam kurikulum masa depan yang memperhatikan keragaman sosial, budaya, ekonomi, dan politik tidak lagi hanya mendasarkan diri pada teori psikologi belajar yang bersifat 
individualistik dan menempatkan anak didik dalam suatu kondisi value free, tetapi harus pula didasarkan pada teori belajar yang menempatkan anak didik sebagai makhluk sosial, budaya, politik, dan hidup sebagai anggota aktif masyarakat, bangsa, dan dunia.

d. Proses belajar yang dikembangkan untuk anak didik juga harus berdasarkan proses yang memiliki tingkat isomorphism yang tinggi dengan kenyataan sosial. Artinya, proses belajar yang mengadalkan anak didik belajar secara individualistis dan bersaing secara kompotitif-individualistis harus ditinggalkan dan diganti dengan cara belajar berkelompok dan bersaing secara kelompok dalam suatu situasi positif. Dengan cara demikian, perbedaan antara individu dapat dikembangkan sebagai suatu kekuatan kelompok dan anak didik terbiasa hidup dengan berbagai keragaman budaya, sosial, intelektualitas, ekonomi, dan aspirasi politik.

e. Evaluasi yang digunakan haruslah meliputi keseluruhan aspek kemampuan dan kepribadian peserta didik, sesuai dengan tujuan dan konten yang dikembangkan. Alat evaluasi yang digunakan haruslah beragam, sesuai dengan sifat tujuan dan informasi yang ingin dikumpulkan, dengan menerapkan penilaian berbasis kelas dengan berbagai ragamnya, seperti portofolio, catatan, observasi, wawancara, performance test, proyek dan produk. ${ }^{17}$

Masyarakat multikultural yang demokratis di Indonesia yang sehat tidak bisa dibangun secara taken for granted atau trial and error, sebaliknya harus diupayakan secara sistematis, programatis, integrated dan berkesinambungan. Salah satu strategi dan wadahnya adalah melalui pendidikan kewarganegaraan. Studi yang dilakukan oleh Arif telah menemukan bahwa peran pendidikan kewarganegaran sebagai program kurikuler, program sosio kultural, maupun program akademik dapat menjadi wahana pendidikan multikultural. ${ }^{18}$ Selain itu, Mahfud menegaskan bahwa Indonesia sebagai negara majemuk, baik dalam segi agama, suku bangsa, golongan, maupun budaya lokal, perlu menyusun konsep pendidikan multikultural sehingga menjadi pegangan untuk memperkuat identitas nasional. Pelajaran Pendidikan Kewarganegaraan $(\mathrm{PKn})$ yang telah diajarkan di sekolah dasar hingga perguruan tinggi, sebaiknya disempurnakan dengan memasukkan pendidikan multikultural, seperti budaya lokal antar daerah ke dalamnya, agar generasi muda bangsa sebagai bangsa Indonesia. ${ }^{19}$

Lebih lanjut menurut Winataputra pendidikan kewarganegaraan untuk Indonesia, secara filosofis dan substantif-pedagogis andragogis, merupakan pendidikan untuk memfasilitasi perkembangan pribadi peserta didik agar menjadi warga negara Indonesia yang religius, berkeadaban, berjiwa persatuan Indonesia, demokratis dan bertanggung jawab, dan berkeadilan, serta mampu hidup secara harmonis dalam konteks multikulturalisme (Bhinneka Tunggal Ika)..$^{20}$ Dalam konteks yang demikian, Pendidikan Kewarganegaraan (PKn) memiliki peranan yang sangat penting dalam upaya mengembangkan masyarakat multikultural.

\section{Pendidikan Multikultural sebagai Alternatif Pemecahan Konflik}

Penyelenggaraan pendidikan multikultural di dunia pendidikan diyakini dapat menjadi solusi nyata bagi konflik dan disharmonisasi yang terjadi di masyarakat, khususnya yang kerap terjadi di masyarakat Indonesia yang secara realitas plural. Dengan kata lain, pendidikan multikultural dapat menjadi sarana alternatif pemecahan konflik sosial budaya.

Spektrum kultur masyarakat Indonesia yang amat meragam menjadi tantangan bagi dunia pendidikan guna mengolah perbedaan tersebut menjadi suatu aset, bukan sumber perpecahan.

18 D.B. Arif, Pengembangan Warga Negara Multikultural Implikasinya Terhadap Kompetensi Kewarganegaraan (Penelitian Grounded Theory dalam Konteks Pendidikan Kewarganegaraan Indonesia). Tesis PPS UPI:tidak diterbitkan, 2008.

19 Choirul Mahfud. Pendidikan Multikultural. Yogyakarta: Pustaka Pelajar, 2010, h. 224.

20 U.S. Winataputra, Multikulturalisme: Bhinneka Tunggal Ika dalam perspektif Pendidikan Kewarganegaraan sebagai Wahana Pembangunan Karakter Bangsa Indonesia Dalam Dialog Multikultural, Bandung: Sekolah Pascasarjana UPI, 2008, h. 31. 
Saat ini, pendidikan multikultural mempunyai tanggung jawab besar, yaitu: menyiapkan bangsa Indonesia untuk siap menghadapi arus budaya luar di era globalisasi dan "menyatukan" bangsa sendiri yang terdiri dari berbagai macam budaya.

Memang, pendidikan kebangsaan dan ideologi telah banyak diberikan di perguruan tinggi, namun pendidikan multikultural belum diberikan pada porsi yang benar. Maka sekolah dan perguruan tinggi sebagai institusi pendidikan dapat mengembangkan pendidikan multikultural dengan model masing-masing sesuai otonomi pendidikan atau sekolah. Pada dasarnya, modelmodel pembelajaran sebelumnya yang berkaitan dengan kebangsaan memang sudah ada namun, hal itu masing kurang memadai sebagai sarana pendidikan guna menghargai perbedaan masing-masing suku, budaya, dan etnis. Hal itu terlihat dengan mumculnya konflik yang kerap terjadi pada realitas kehidupan berbangsa dan bernegara saat ini. Hal itu menunjukkan bahwa pemahaman toleransi masih amat kurang.

Hingga saat ini, jumlah siswa dan mahasiswa yang memahami apa yang apa sebenarnya ada di balik budaya suatu bangsa masih sangat sedikit. Menurut Suyanto, seorang pakar pendidikan, masyarakat justru mengetahui lebih dalam mengenai stereotip suatu suku bangsa dibandingkan mengenal apa yang sebenarnya dimiliki suku tersebut. Padahal dalam diskursus pendidikan multikultural memahami makna di balik realitas budaya suatu bangsa itu merupakan hal yang esensial. ${ }^{21}$ Karena itu penyelenggaraan pendidikan multikularal dapat dikatakan berhasil bila terbentuk pada diri siswa dan mahasiswa sikap hidup toleran, tidak bermusuhan dan tidak berkonflik yang disebabkan oleh perbedaan budaya, adat, suku, bahasa, adat istiadat atau yang lainnya.

Menurut Stepen Hill, Direktur Perwakilan Badan PBB Bidang Pendidikan, Ilmu Pengetahuan dan Budaya (UNESCO) untuk kawasan Indonesia, Malaysia, Filipina, dan Timor Leste, pendidikan multikultural dapat dikatakan berhasil apabila prosesnya melibatkan semua elemen masyarakat. Secara konkret, pendidikan ini tidak hanya melibatkan guru ataupun pemerintah saja namun seluruh elemen masyarakat. Hal itu dikarenakan adanya multidimensi aspek kehidupan yag tercakup dalam pendidikan multikultural.

Perubahan yang diharapkan dalam konteks pendidikan multikultural ini tidak terletak pada justifikasi angka atau statistik dan berorientasi kognitif anisch sebagaimana lazim penilaian keberhasilan pelaksanaan pendidikan di negeri ini. Namun, lebih dari itu pada terciptanya kondisi yang nyaman, damai, toleran dalam kehidupan masyarakat, dan tidak selalu muncul konflik yang disebabkan oleh perbedaan budaya dan SARA.

Selain sebagai alternatif mencegah konflik menurut Fuad Hassan, pendidikan multikultural secara signifikan juga dapat membina siswa agar tidak tercabut dari akar budaya yang ia miliki sebelumnya, tatkala ia berhadapan dengan realitas sosial budaya di era globalisasi. Dalam era globalisasi saat ini, pertemuan antarbudaya menjadi "ancaman" serius bagi anak didik sebab anak didik di Indonesia masa kini dalam banyak hal jauh berbeda dengan anak-anak seuisanya di masa lalu. Berbagai budaya yang sudah ada di negeri ini berbaur dengan banyak budaya asing yang kian mudah diperoleh melalui beragam media, sepeti internet, televisi, dan lain-lain. Kemajuan ilmu pengetahuan dan teknologi memperpendek jarak dan memudahkan adanya persentuhan antarbudaya. ${ }^{22}$

Dari tanggapan Fuad Hasaan di atas dapat kita analisis bahwa tantangan dalam dunia pendidikan kita saat ini sangat kompleks. Maka, upaya antisipasi perlu dipikirkan secara serius karena pendidikan kita yang bertanggung jawab penuh atas kualitas sumber daya manusia di negeri ini. Jika tidak anak-anak generasi bangsa ini bisa kehilangan arah dan tercabut dari akar budayanya sendiri, karena jika yang terjadi adalah persingunggan antar dua budaya yang berbeda itu mungkin masih mudah diatasi. Tetapi dalam era globalisasi saat ini pertemuan antarbudaya sudah luar biasa kompleks. Maka jelas dimungkinkan terjadinya tarik ulur yang saling mempengaruhi antarbudaya dan sangat dimungkinkan kekhawatiran Samuel P. Huntington dalam tesisnya The Clash Civilization akan terwujud. Dengan demikian pendidikan multikultural tidak dapat ditawar-tawar lagi, sudah saatnya pendidikan di Indonesia
22 Ibid, h. 220 . 
memberikan perhatian besar pada pendidikan multikultural yang secara tidak langsung hal itu dapat memberikan solusi bagi sejumlah permasalah sosial yang dihadapi bangsa Indonesia mendatang.

\section{Penutup}

Suatu kenyataan yang tidak dapat dipungkiri bahwa bangsa Indonesia terdiri dari berbagai keragaman yaitu sejumlah besar kelompok etnis, budaya, agama, aspirasi politik dan lain sebagainya. Keragaman ini dapat menjadi rahmat sekaligus bencana apabila sesama anak bangsa tidak memahami hakikat berbangsa dan bernegara dalam naungan Bhineka tunggal Ika. Nyatanya kebhinekaan tersebut justru menjadi pemicu konflik yang dikhawatirkan berakhir pada disintegrasi bangsa sehingga pendidikan multikultural bagi pengembangan masyarakat menjadi kebutuhan bagi bangsa Indonesia karena pendidikan multikultural pada dasarnya menekankan pada kesederajatan kebudayaan yang ada dalam sebuah masyarakat, dan mengusung semangat untuk hidup berdampingan secara damai (peaceful coexistence) dalam perbedaan kultur yang ada, baik secara individual maupun secara kelompok dalam sebuah masyarakat.

Masyarakat multikultural yang demokratis di Indonesia yang sehat tidak bisa dibangun secara taken for granted atau trial and error, sebaliknya harus diupayakan secara sistematis, programatis, integrated dan berkesinambungan. Untuk itu, pendidikan multikultural di Indonesia harus mengembangkan model pembelajaran yang mengarah pada beberapa kompetensi dasar yang harus dimiliki warga negara yakni. Pertama, mengembangkan kompetensi akademik standar dan dasar (standar and basic academic skills) tentang nilaipersatuan dan kesatuan, demokrasi, keadilan, kebebasan, persamaan derajat atau saling menghargai dalam beraneka jenis keberagaman. Kedua, mengembangkan kompetensi sosial agar dapat menumbuhkan pemahaman yang lebih baik (a better understanding) tentang latar belakang budaya dan agama sendiri dan juga budaya dan agama lain dalam masyarakat. Ketiga, mengembangkan kompetensi akademik untuk menganalisis dan membuat keputusan yang cerdas (intelegent dicisions) tentang isu-isu dan masalah keseharian (real life problems) melalui sebuah proses demokratis atau penyelidikan dialogis (dialogical inquiry). Keempat, membantu mengkonseptualisasi dan mengaspirasikan konstruksi masyarakat yang lebih baik, demokratis, egaliter, tanpa ada diskriminasi, penindasan, dan pelanggaran terhadap nilai asasi universal.

\section{Daftar Pustaka}

Andersen, R. dan Cusher, K. Multicultural and intercultural studies, dalam Teaching Studies of Society and Environment (ed. Marsh,C.). Sydney: Prentice-Hall. 1994.

Azra, Azyumardi. "Pendidikan Kewargaan dan demokrasi di Indonesia, dalam Ikhwanuddin Syarif \& Domodo Murtadlo (eds), Pendidikan untuk masyarakat Indonesia baru: 70 Tahun Prof. Dr. HAR Tilaar MscEd (Jakarta:Grasindo). 2002.

Arif, D. B. Pengembangan Warga Negara Multikultural Implikasinya Terbadap Kompetensi Kewarganegaraan (Penelitian Grounded Theory dalam Konteks Pendidikan Kewarganegaraan Indonesia). Tesis PPS UPI:tidak diterbitkan. 2008.

Banks, J. A. Educating Citizens in a Multikultural Society. Teachers College Columbia University New York and London. 1997

Blum, L.A. (2001) "Antirasisme, Multikulturalisme, dan Komunitas Antar-Ras: Tiga Nilai yang Bersifat Mendidik bagi Sebuah Masyarakat Multikultural". Dalam May, Larry, Shari Collins-Chobanian, and Kai Wong (Eds). Etika Terapan I: Sebuah Pendekatan Multikultural.

Budimansyah, D dan Suryadi.PKn dan Masyarakat Multikultural, Bandung: Program Studi PKn SPs UPI. 2008.

Cuga, Candra. Pendidikan Kewarganegaraan Sebagai Wahana Pendidikan Multikultural Dalam Membina Kesadaran Demokrasi Warganegara.

Tesis PPS UPI:tidak diterbitkan. 2012.

Cogan, J.J. dan Derricot, R. Citizenship for the 21 Century: An International Perspective on Education. London: Kogan Page. 1998.

Hernandez, Hilda. Multikultural Education: A Teacher Guide to Linking Context, Process, and Content. New Jersey \& Ohio: Prentice 
Hall. 1989.

Jumadi. Dinamika konflik sosial dalam bentuke tawuran mahasiswa di Kota Makassar". Disertasi PPS UNHAS: tidak diterbitkan. 2009.

Mahfud, C. Pendidikan Multikultural. Yogyakarta: Pustaka Pelajar. 2010.

Maslikhah. Quo Vadis Pendidikan Multikultural Rekonstruksi Sistem Pendidikan Berbasis Kebangsaan. Jawa Tengah: JP Books. 2007.

Naim, Ngainun dan Sauqi, A. Pendidikan Multikultural Konsep dan Aplikasi. Yogyakarta: Ar-Ruzz Media Group. 2011.

Purwasito, Andrik. Komunikasi Multikultural, Surakarta : UMS Press. 2003.
Sapriya \& Winataputra, U. S. Pendidikan Kewarganegaraan: Model Pengembatan Materi dan Pembelajaran. Laboratorium Pendidikan Kewarganegaraan-FPIPS UPI. 2003.

Tilaar H.A.R. Multikulturalisme, TantanganTantangan Global Masa Depan dalam Transformasi Pendidikan Nasional, Jakarta: Grasindo. 2004.

Winataputra. U.S. Multikulturalisme: Bbinneka Tunggal Ika dalam perspektif Pendidikan Kewarganegaraan sebagai Wahana Pembangunan Karakter Bangsa Indonesia Dalam Dialog Multikultural. Bandung: Sekolah Pascasarjana UPI. 2008. 